\title{
Pemberdayaan Masyarakat Agribisnis Berbasis Pemanfaatan Sumber Daya Lokal Limbah Batang Tembakau sebagai Pewarna Alami Batik di Desa Tamansari
}

\author{
Bekti Palupi, Istiqomah Rahmawati, Meta Fitri Rizkiana \\ Fakultas Teknik, Universitas Jember \\ bekti.palupi@unej.ac.id
}

\begin{abstract}
Abstrak
Jember memiliki komoditas tembakau yang cukup melimpah, salah satu daerah penghasil tembakau adalah di kawasan Wuluhan. Program Pengabdian Masyarakat Fakultas Teknik, Universitas Jember dengan mitra yaitu Kelompok Tani Karunia Tembakau yang terletak di Desa Tamansari, bertujuan untuk mengatasi permasalahan mitra. Bagian tembakau yang laku dijual para petani adalah daun tembakau, sedangkan batang tembakau tidak dimanfaatkan dan menumpuk menjadi limbah. Upaya mengurangi limbah batang tembakau dan menambah nilai guna dapat dilakukan dengan memanfaatkan batang tembakau menjadi pewarna alami batik. Penggunaan pewarna alami pada kain batik juga berkontribusi dalam mengurangi pencemaran lingkungan yang disebabkan oleh penggunaan pewarna sintetis pada industri batik. Pewarna alami dari batang tembakau dapat dimanfaatkan oleh pengrajin batik yang ada di wilayah Jember dan sekitarnya. Pemberdayaan masyarakat dalam pengolahan batang tembakau menjadi pewarna alami batik diharapkan mampu meningkatkan ekonomi Kelompok Tani Karunia Tembakau di Desa Tamansari. Penyelesaian masalah dari mitra dilakukan dalam skema pengabdian masyarakat dengan tahapan pemberian sosialisasi tentang pengelolaan dan pengolahan limbah batang tembakau menjadi pewarna alami batik, menginisiasi dan memberikan bantuan kepada masyarakat contoh satu set alat produksi pewarna alami dalam skala rumah tangga, pemberian sosialisasi terkait proses pengemasan dan pemasaran produk, serta menginisiasi proses pemasaran produk dengan mengundang distributor dan konsumen potensial. Hasil dari program pengabdian masyarakat ini adalah diharapkan Kelompok Tani Karunia Tembakau Desa Tamansari mampu mengolah limbah batang tembakau menjadi pewarna alami batik secara mandiri dan kontinyu.
\end{abstract}

Kata kunci: Batang tembakau, Pewarna alami batik, Desa Tamansari

\begin{abstract}
Jember has abundant tobacco commodities, one of the tobacco producers in the Wuluhan region. The Community Service Program of Engineering Faculty, University of Jember, with partners, namely the Karunia Tembakau Farmer's Group located in Tamansari Village, to overcome partner difficulties. The part of tobacco sold by farmers is tobacco leaves, while tobacco stalks are not used and accumulate into waste. Efforts to reduce tobacco waste and add value can be done by utilizing tobacco stalks into batik's natural dyes. The use of batik's natural dyes also contributes to reducing environmental pollution caused by the use of synthetic dyes in the batik industry. Natural dyes from tobacco stalks can be used by batik artisans in the Jember region and beyond. Community empowerment in managing tobacco stalks into batik's natural dyes is expected to increase prosperity of Karunia Tembakau Farmer's Group in Tamansari Village. Problem solving from partners is carried out in the completion of community service by completing the dissemination of management and processing of tobacco stalks into batik's natural dyes, initiating and providing assistance to the community for example a set of natural dye production equipment in the household, socialization assistance related to the product packaging and sales process and initiate the product marketing process by inviting distributors and potential consumers. The result of this community service program is expected that the Karunia Tembakau Farmer's Group of Tamansari Village will be able to process tobacco waste into batik's natural dyes independently and continuously.
\end{abstract}

Keywords: tobacco stalks, batik's natural dyes, Tamansari Village 


\section{PENDAHULUAN}

\section{A. Analisis Situasi}

Indonesia merupakan negara agraris sehingga sektor pertanian menjadi salah satu roda penggerak perekonomian masyarakat Indonesia. Berdasarkan data dari Badan Pusat Statistik (BPS) pada triwulan II 2017, hasil pertanian selalu memberikan sumbangan untuk perekonomian nasional. Sumbangan dari produk domestik bruto Indonesia mencapai 3.366,8 triliun (Data BPS, 2017).

Salah satu sumber daya alam dari sektor pertanian dan perkebunan yang cukup melimpah di Indonesia adalah tembakau. Penyumbang produksi tembakau terbesar di Indonesia adalah Provinsi Jawa Timur, diantaranya yaitu Kabupaten Jember. Berdasarkan data statistik Perkebunan Indonesia tahun 2017, produksi tembakau di Jember sebanyak 3.949 ton (Data BPS, 2017). Dengan adanya sumber tembakau yang cukup banyak tersebut, maka terdapat banyak petani tembakau yang ada di wilayah Jember.

Tembakau merupakan tanaman dengan tinggi kira-kira 1,8 meter dan lebar daunnya bisa mencapai $30 \mathrm{~cm}$ (Herawati, 2016). Khusus di Jember, tanaman tembakau yang banyak ditanam adalah tembakau Besuki seperti pada Gambar 1. Penanaman tembakau di Indonesia sudah dimulai sejak tahun 1830. Di daerah Besuki, Jawa Timur, tanaman tembakau mulai dikembangkan pada tahun 1856. Tembakau besuki digunakan sebagai pembalut atau pengisi dalam industri rokok. Tembakau jenis ini dikenal memiliki bau yang harum dan kualitas bagus untuk industri rokok.

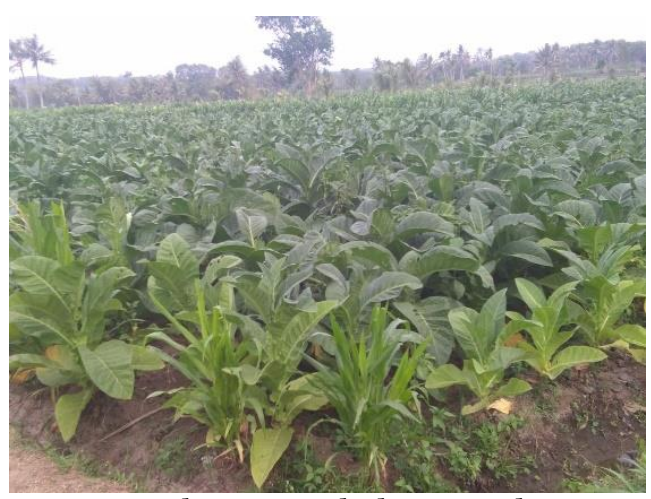

Gambar l. Tembakau Besuki

Berdasarkan waktu tanam, tembakau besuki dikategorikan menjadi dua jenis yaitu tembakau besuki Na Oogst (NO) dan tembakau besuki Voor Oogst (VO). Tembakau besuki NO biasa ditanam pada musim penghujan, sedangkan tembakau besuki VO ditanam pada musim kemarau. Daun tembakau sebagian besar dimanfaatkan untuk industri rokok, sedangkan batangnya hanya dibuang sebagai limbah seperti pada Gambar 2. Oleh karena itu, limbah batang tembakau perlu ditangani agar tidak mengganggu masyarakat dan mengurangi estetika lingkungan. Salah satu upaya yang bisa dilakukan untuk menangani limbah batang tembakau tersebut adalah mengkonversinya menjadi pewarna alami batik sehingga memiliki nilai tambah. 


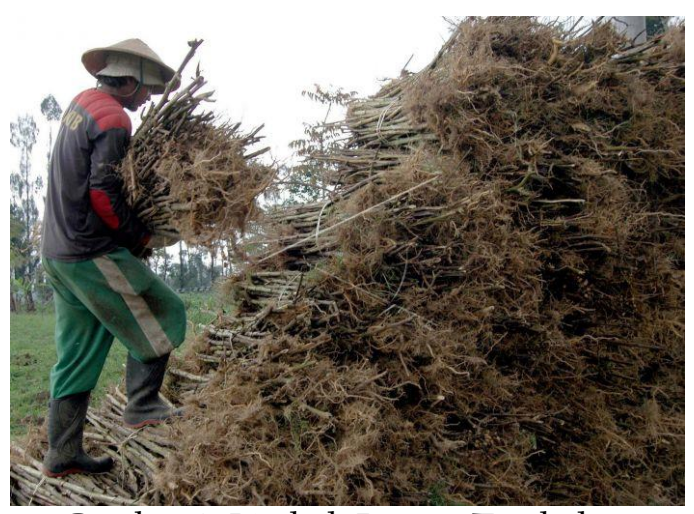

Gambar 2. Limbah Batang Tembakau

Pemilihan batang tembakau untuk dijadikan sebagai pewarna alami batik dikarenakan Jember juga merupakan salah satu produsen batik yang cukup terkenal. Isu pewarna sintetis pada batik yang mencemari lingkungan dapat diatasi dengan menggunakan pewarna alami. Pewarna alami tersebut salah satunya bisa didapatkan dari batang tembakau. Warna yang dihasilkan dari batang tembakau tersebut adalah cokelat. Dengan demikian, petani bisa mendapatkan nilai tambah dari batang tembakau yang semula hanya sebagai limbah menjadi pewarna alami batik. Pewarna tersebut dapat dijual ke produsen batik yang ada di wilayah Jember sehingga perekonomian lokal masyarakat Jember bisa terangkat dengan sinergi antara petani dan pengusaha batik.

\section{Identifikasi Permasalahan yang Dihadapi}

\section{B.Permasalahan Mitra}

Berdasarkan analisis situasi dan kondisi lingkungan di atas, ada beberapa persoalan terkait dengan limbah batang tembakau pada Tabel 1 berikut.

Tabel l. Persoalan di Desa Tamansari, Wuluhan, Jember

\begin{tabular}{lcl}
\hline No. & \multicolumn{1}{c}{ TINJAUAN } & \multicolumn{1}{c}{ 2.PERSOALAN } \\
\hline 1 & Limbah batang tembakau & $\begin{array}{l}\text { Bagian tembakau yang laku dijual oleh petani adalah } \\
\text { daunnya, sedangkan batangnya hanya ditumpuk dan } \\
\end{array}$ \\
& $\begin{array}{l}\text { menjadi limbah. Limbah batang tembakau ini } \\
\text { mengganggu dan mengurangi estetika lingkungan. }\end{array}$ \\
$2 \quad \begin{array}{l}\text { Pengolahan dan } \\
\text { pengelolaan limbah } \\
\text { batang tembakau }\end{array}$ & $\begin{array}{l}\text { Petani tembakau perlu memikirkan cara untuk } \\
\text { menangani limbah tersebut sehingga tidak mengganggu }\end{array}$ \\
& $\begin{array}{l}\text { lingkungan dan bisa memberikan nilai tambah yang } \\
\text { menunjang perekonomian. }\end{array}$ \\
\hline
\end{tabular}

Dari analisis situasi di atas maka muncul persoalan terkait evaluasi pengelolaan dan pengolahan limbah batang tembakau di Kelompok Tani Karunia Tembakau, diantaranya:

a) Penumpukan jumlah batang tembakau yang bisa mengganggu dan mengurangi estetika lingkungan.

b) Kurangnya pengetahuan para petani tembakau untuk mengelola dan mengolah limbah batang tembakau menjadi produk lain yang memiliki daya jual lebih.

c) Justifikasi Prioritas Penyelesaian Permasalahan yang Ditangani

Sesuai urutan identifikasi masalah di atas, maka penyelesaian persoalan dimulai dengan:

1) Sosialisasi tentang pengelolaan dan pengolahan limbah batang tembakau menjadi produk lain (difokuskan pada pembuatan pewarna alami batik dari batang tembakau) yang memiliki daya jual tinggi. 
2) Menginisiasi dan memberikan bantuan kepada masyarakat contoh satu set alat produksi pewarna alami dalam skala rumah tangga yang dipergunakan sebagai media produksi pewarna alami batik dari batang tembakau.

3) Memberikan sosialisasi terkait proses pengemasan dan pemasaran produk.

4) Menginisiasi proses pemasaran produk dengan mengundang distributor dan konsumen potensial.

Tahap-tahap penyelesaian di atas telah mampu membantu menyelesaikan masalah pengelolaan limbah batang tembakau di Kelompok Tani Karunia Tembakau, Desa Tamansari, Wuluhan, Jember.

\section{SOLUSI DAN METODE}

\section{A. Solusi yang Ditawarkan}

Permasalahan yang dapat teridentifikasi dari pihak mitra adalah masalah tumpukan limbah batang tembakau yang dapat mengganggu masyarakat dan estetika lingkungan. Penanganan untuk mengurangi limbah batang tembakau sekaligus meningkatkan nilai ekonomisnya adalah limbah batang tembakau tersebut dimanfaatkan menjadi pewarna alami dalam industri pembuatan batik. Batik merupakan kerajinan tangan khas Indonesia. Proses pewarnaan batik merupakan salah satu faktor yang mempengaruhi kualitas kain batik. Penggunaan bahan pewarna alami dapat turut berkontribusi mengurangi pencemaran lingkungan.

Dalam rangka memanfaatkan limbah batang tembakau dan guna mendukung efisiensi dan efektifitas program pengabdian kepada masyarakat ini, maka diajukan kerangka pemecahan masalah yang meliputi empat hal. Pertama, tim pengabdian disyaratkan memiliki kompetensi kimia dan formulasi kimia yang baik guna melaksanakan tahapan proses ekstraksi pewarna batik dari limbah batang tembakau. Kedua, persiapan pelaksanaan pengabdian masyarakat harus dilakukan secara menyeluruh, terutama tentang materi pelatihan, praktek pembuatan pewarna secara langsung, dan media pembelajaran yang komunikatif dan menarik. Ketiga, evaluasi program pengabdian yang dilakukan secara bertahap baik mengenai materi pelatihan, peserta, dan penyelenggaraan acara sosialisasi. Keempat, tidak terbatas pada acara sosialisasi, peserta juga diinisiasi terkait proses pemasaran produk kepada pengrajin-pengrajin batik di kawasan Jember dan sekitarnya.

\section{B.Metode Pelaksanaan}

Kegiatan pengabdian masyarakat dilaksanakan pada Oktober - Desember 2018 di salah satu rumah petani tembakau.

\section{Perencanaan Sosialisasi dan Pembekalan Manajemen Pengelolaan dan Pengolahan Limbah Batang Tembakau}

Materi sosialisasi dan pembekalan serta tujuan dari pemberian materi dijelaskan pada Tabel 2 berikut.

Tabel 2. Materi Sosialisasi dan Pembekalan Kegiatan Pengabdian Masyarakat

\begin{tabular}{|c|c|c|c|}
\hline No. & Jenis Materi Pembekalan & $\begin{array}{c}\text { Tujuan Pemberian } \\
\text { Materi }\end{array}$ & Peserta Pembekalan \\
\hline 1 & $\begin{array}{l}\text { Sosialisasi tentang } \\
\text { pengelolaan dan } \\
\text { pengolahan limbah batang } \\
\text { tembakau menjadi produk } \\
\text { lain (difokuskan pada } \\
\text { pembuatan pewarna alami } \\
\text { batik) yang memiliki daya } \\
\text { jual tinggi }\end{array}$ & $\begin{array}{l}\text { Untuk memastikan } \\
\text { masyarakat mampu } \\
\text { melakukan } \\
\text { pengelolaan limbah } \\
\text { batang tembakau } \\
\text { menjadi pewarna alami } \\
\text { batik }\end{array}$ & $\begin{array}{l}\text { Petani Tembakau di } \\
\text { Kelompok Tani Karunia } \\
\text { Tembaku, } \\
\text { Tamansari, Wesa } \\
\text { Jember, serta masyarakat } \\
\text { sekitar }\end{array}$ \\
\hline
\end{tabular}


Sosialisasi dan pembekalan terkait pengelolaan dan pengolahan limbah batang tembakau menjadi produk lain merupakan pendukung dari kegiatan pengabdian masyarakat sehingga kegiatan pengabdian dapat terlaksana dan berjalan dengan baik.

\section{Pelaksanaan Kegiatan Pembuatan Pewarna Alami dari Limbah Batang Tembakau}

Setelah dilakukan sosialisasi dan evaluasi, langkah selanjutnya adalah pengolahan limbah batang tembakau menjadi pewarna alami yang disebut sebagai proses ekstraksi. Proses ekstraksi sendiri dapat dilakukan dengan dua metode sesuai dengan bahan baku yang tersedia.

a. Proses Ekstraksi Batang Tembakau Basah

Zat warna pada batang tembakau basah dapat diekstraksi dengan cara ditumbuk lalu diperas agar diperoleh zat warna alami dari batang tembakau basah. Secara terperinci terdapat beberapa tahapan untuk ekstraksi zat warna dari batang tembakau, yakni proses cuci, proses tumbuk/penghancuran, proses peras, dan proses filtrasi.

Hasil ekstrak batang tembakau harus disaring terlebih dahulu sebelum dapat digunakan sebagai zat warna alami. Proses penyaringan sendiri dilakukan untuk memisahkan zat padat atau kontaminan dengan ekstrak batang tembakau. Filtrat yang dihasilkan dapat langsung dipergunakan sebagai zat warna alami untuk mewarnai batik.

b. Proses Ekstraksi Batang Tembakau Kering

Pada batang tembakau kering, proses ekstraksi zat warna berbeda dengan batang tembakau basah. Proses ekstraksi pada batang tembakau basah secara umum dilakukan dengan cara mekanik yakni dengan proses penumbukan. Namun, karena kadar air pada batang tembakau sudah sangat sedikit maka proses ekstraksi dilakukan dengan bantuan panas dari luar yakni dengan proses perebusan. Panas sendiri menyebabkan molekulmolekul zat warna lebih mudah berinteraksi dengan pelarut air seperti halnya pada proses penumbukan.

Proses filtrasi dilakukan untuk memisahkan ekstrak zat warna batang tembakau dengan retentat batang tembakau kering. Hasil ekstraksi zat warna dari batang tembakau kering cenderung lebih stabil dibandingkan batang tembakau basah. Hal ini dikarenakan, pada batang tembakau basah menghasilkan warna hijau di awal proses ekstraksi dan mengalami perubahan menjadi cokelat akibat dari reaksi degradasi zat warna. Sementara pada ekstrak limbah batang tembakau kering, warna ekstrak cenderung stabil yakni cokelat.

\section{Perencanaan Sosialisasi Proses Pewarnaan Kain Batik dengan Menggunakan Zat Warna Alami}

Materi sosialisasi dan pembekalan serta tujuan dari pemberian materi dijelaskan pada Tabel 3 berikut.

Tabel 3 Materi Sosialisasi dan Pembekalan Kegiatan Pengabdian Masyarakat

\begin{tabular}{|c|c|c|c|}
\hline No. & Jenis Materi Pembekalan & $\begin{array}{c}\text { Tujuan Pemberian } \\
\text { Materi }\end{array}$ & Peserta Pembekalan \\
\hline 1 & $\begin{array}{l}\text { Sosialisasi tentang proses } \\
\text { pewarnaan kain batik } \\
\text { dengan zat warna alami }\end{array}$ & $\begin{array}{l}\text { Memberikan } \\
\text { pengetahuan terkait } \\
\text { proses pewarnaan kain } \\
\text { batik dengan zat } \\
\text { warna alami }\end{array}$ & $\begin{array}{l}\text { Petani tembakau di } \\
\text { Kelompok Tani Karunia } \\
\text { Tembakau, Desa } \\
\text { Tamansari, Wuluhan, } \\
\text { Jember, serta masyarakat } \\
\text { sekitar }\end{array}$ \\
\hline
\end{tabular}

Sosialisasi dan pembekalan terkait Proses Pewarnaan Kain Batik dengan Menggunakan Zat Warna Alami merupakan pendukung dari kegiatan pengabdian masyarakat sehingga kegiatan pengabdian dapat terlaksana dan berjalan dengan baik. 
4. Pewarnaan Kain Batik dengan Zat Warna Alami berikut:

Proses pewarnaan kain batik bermotif dilakukan melalui beberapa tahapan sebagai

a. Proses cuci

Kain batik yang akan diwarnai dengan zat warna alami harus dicuci dulu dengan menggunakan TRO (Turkies Red Oil). Penggunaan TRO dimaksudkan untuk menghilagkan kotoran pada kain batik yang dapat menghalangi interaksi antara polimer yang menyusun kain batik dengan zat warna alami. Perbandingan antara jumlah Turkies Red Oil dengan air adalah 1 sendok makan:5 liter air yang dapat dipergunakan untuk merendam 3 buah kain batik dengan ukuran $2 \mathrm{~m} 2$ atau hingga rendaman berwarna putih susu yang berarti rendaman tersebut sudah kotor (Dyaninoor, 2012).

b. Proses pengeringan

Proses pengeringan tidak dilakukan secara langsung di bawah sinar matahari. Proses pengeringan cukup dilakukan dengan menjemur kain di ruangan terbuka hingga air tidak menetes lagi.

\section{c. Proses Penyelupan}

Proses pewarnaan kain batik dengan pewarna alami dilakukan dengan penyelupan. Proses penyelupan kain batik dilakukan berulang kali untuk memastikan kain batik sudah benar-benar terwarnai dengan sempurna. Membutuhkan sekitar 3 liter zat warna alami untuk mewarnai kain batik dengan ukuran $2 \mathrm{~m} 2$ (Dyaninoor, 2012). Proses penyelupan sendiri dilakukan hingga 20 kali (selama 15 menit/penyelupan) dan untuk setiap penyelupan kain batik harus dikeringkan kembali agar dapat diprediksi hasil degradasi warna kain batik sudah sesuai dengan yang diinginkan konsumen.

d. Proses Fiksasi ke Zat Pengunci Warna

Proses pewarnaan batik dengan menggunakan zat warna alami memerlukan bahan aditif lain yang berguna untuk mempertahankan zat warna alami yang cenderung larut dalam pelarut air. Zat pengunci yang banyak dipergunakan dalam industri batik dalah perpaduan antara kapur, tawas dan tunjung (fero sulfat) yang dilarutkan dalam air dengan komposisi 2:2:2:40 (w/w). Proses penguncian zat warna alami pada kain batik sendiri dilakukan setiap kain selesai dijemur setelah dilakukan penyelupan pada zat warna. Proses penguncian zat warna sendiri juga dilakukan selama 15 menit setelah itu kain batik dijemur kembali di ruangan terbuka dan teduh.

\section{HASIL DAN PEMBAHASAN}

Program pengabdian kepada masyarakat berupa pemanfaatan limbah batang tembakau menjadi pewarna alami batik telah dilaksanakan dengan baik, terstruktur, dan melibatkan masyarakat langsung. Kegiatan ini dilaksanakan pada Kelompok Tani Karunia Tembakau Desa Tamansari, Wuluhan sejumlah 20 orang. Detail hasil dan pembahasan kegiatan pengabdian masyarakat dapat diuraikan sebagai berikut.

\section{A. Sosialisai Manajemen Pengelolaan dan Pengolahan Limbah Batang Tembakau}

Kegiatan sosialisasi tentang manajemen pengelolaan dan pengolahan limbah batang tembakau bertujuan untuk memberikan informasi kepada Kelompok Tani Karunia Tembakau bahwa batang tembakau tersebut dapat dimanfaatkan dan menambah nilai guna jika dimanfaatkan sebagai pewarna alami batik. Zat pewarna dalam batang tembakau dapat di-ekstrak dengan pelarut air. Kegiatan sosialisasi ini dilaksanakan pada tanggal 10 November 2018 di rumah salah satu petani tembakau. Kegiatan meliputi pemaparan materi tentang pengelolaan dan pengolahan limbah batang tembakau dan diskusi dengan para peserta terkait materi. Hasil diskusi kegiatan ini diketahui bahwa petani tembakau belum mengetahui bahwa batang tembakau dapat digunakan sebagai pewarna alami batik. Selama 
ini, petani tembakau lebih memilih menumpuk batang tembakau, membuang batang tembakau, atau membakarnya. Kegiatan sosialisasi ini juga menekankan kepada petani tembakau tentang pengurangan pencemaran lingkungan yang bisa dilakukan apabila batang tembakau yang selama ini tidak digunakan dapat dimanfaatkan sebagai pewarna alami batik.

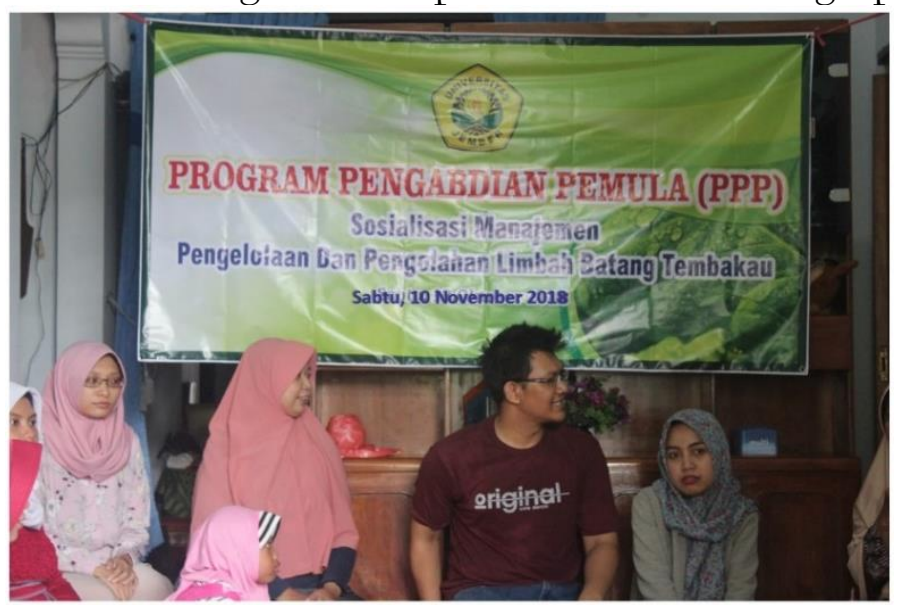

Gambar 3. Sosialisasi Pengelolaan dan Pengolahan Limbah Batang Tembakau

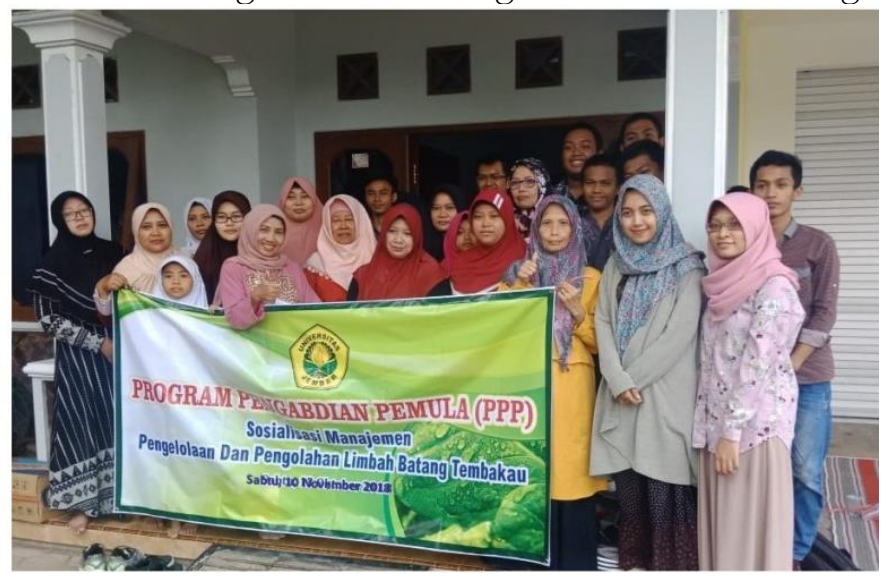

Gambar 4. Foto Bersama dengan Kelompok Tani Karunia Tembakau

\section{B. Kegiatan Pembuatan Pewarna Alami dari Limbah Batang Tembakau}

Kegiatan pembuatan pewarna alami dari limbah batang tembakau dilakukan dalam skala laboratorium dan dilaksanakan di laboratorium Operasi Teknik Kimia Fakultas Teknik Universitas Jember. Kegiatan ini meliputi:

1. Penghancuran Batang Tembakau

Batang tembakau yang dihasilkan setelah masa panen dikumpulkan dan dihancurkan dengan mesin pencacah. Proses penghancuran ini dilakukan di Laboratorium Kemasan Teknik Mesin Fakultas Teknik Universitas Jember. Batang tembakau yang sudah dihancurkan dapat dilihat pada Gambar 5 sebagai berikut. 


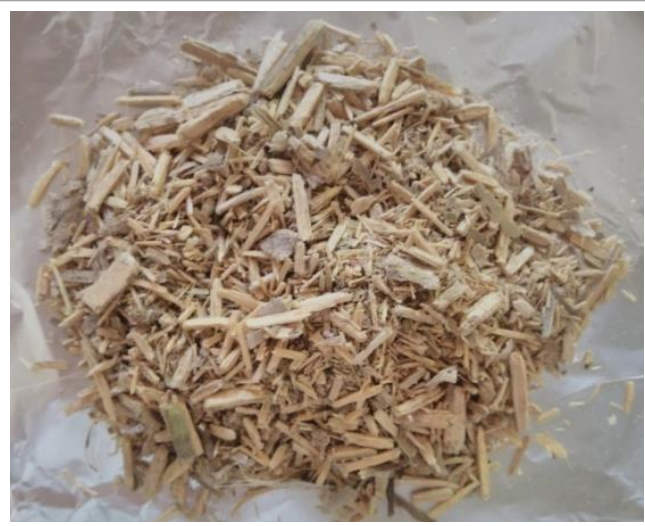

Gambar 5. Batang Tembakau yang Sudah Dihancurkan

\section{Proses Perebusan Batang Tembakau}

Batang tembakau kering yang sudah dihancurkan direbus dengan air. Perbandingan antara batang tembakau dan air adalah l:1. Proses perebusan dapat dilihat pada Gambar 6.

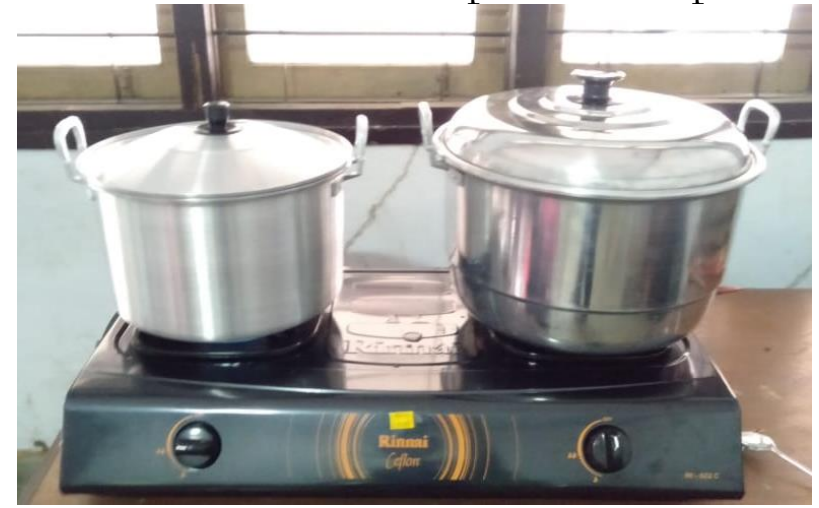

Gambar 6. Proses Perebusan

\section{Proses Filtrasi}

Batang tembakau yang sudah direbus selanjutnya disaring dengan alat penyaring sehingga didapatkan warna cokelat seperti pada Gambar 7.

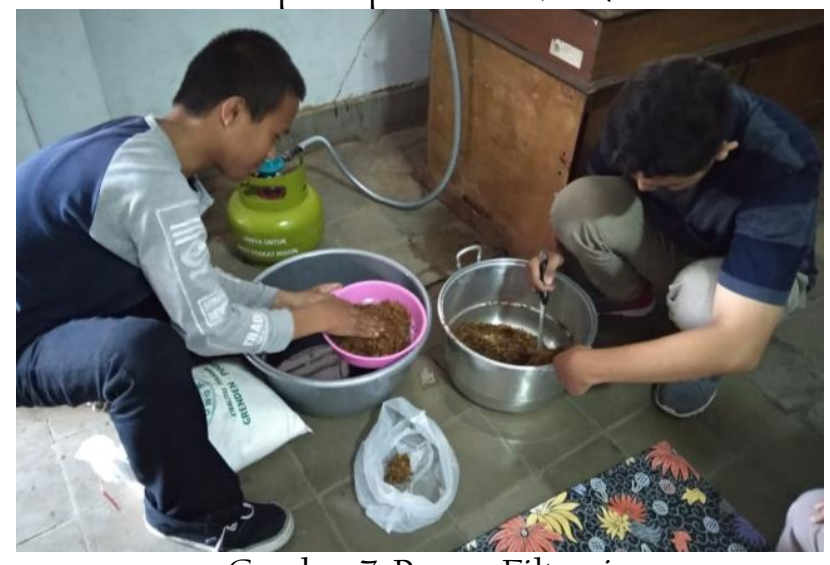

Gambar 7. Proses Filtrasi

\section{Proses $\mathrm{Cuci}$}

Proses pewarnaan dilakukan pada kain putih primisima yang sama dengan kain yang biasa digunakan untuk pembuatan batik. Proses cuci ini menggunakan TRO yang bertujuan untuk mengikat zat warna. TRO yang digunakan sebanyak 1 sendok makan dan dilarutkan dalam air sebanyak 2 L. Setelah TRO dipanaskan sampai mendidih, maka kain putih 
dimasukkan ke dalam larutan tersebut dan dipanaskan sampai dengan 1 jam. Proses ini dapat dilihat pada Gambar 8 .

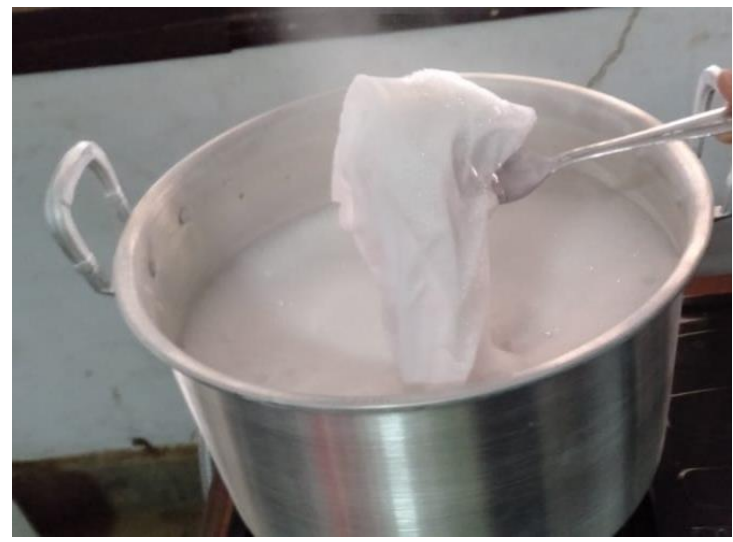

Gambar 8. Proses Cuci

5.Proses Penyelupan

Kain yang sudah dicuci menggunakan TRO selanjutkan dicelupkan ke dalam pewarna alami dari batang tembakau sambil dipanaskan seperti pada Gambar 9. Kain dicelup sampai terjadi perubahan warna.

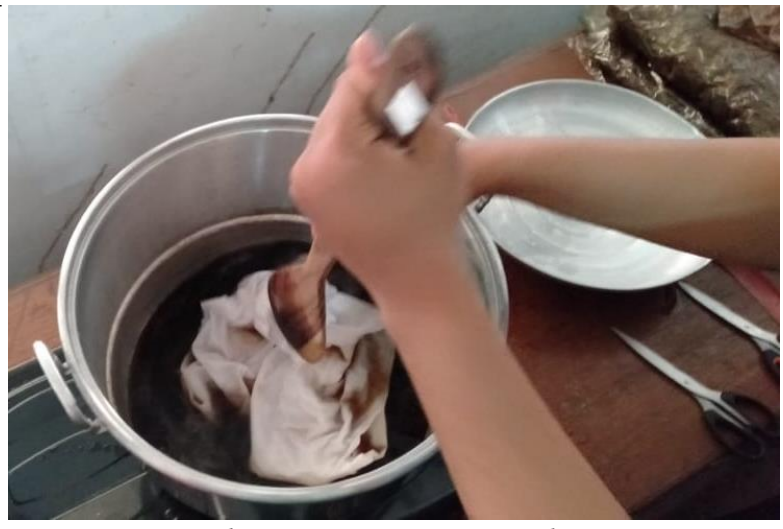

Gambar 9. Proses Penyelupan

\section{Proses Penguncian Warna}

Kain yang sudah diwarnai kemudian dikeringkan dengan cara dijemur. Setelah kering, proses selanjutnya adalah penguncian zat warna dengan menggunakan kapur, tawas dan tunjung (fero sulfat) yang dilarutkan dalam air dengan komposisi 2:2:2:40 (w/w).

\section{Sosialisasi Proses Pewarnaan Kain Batik dengan Pewarna Alami}

Setelah dilakukan percobaan dalam skala laboratorium, maka pada tanggal 17 November 2018 dilakukan sosialiasi metode pewarnaan ke Kelompok Tani Karunia Tembakau. Kegiatan sosialisasi ini dilakukan dengan cara penyampaian materi tentang tahapan pembuatan batang tembakau menjadi pewarna alami batik, tahapan proses pewarnaan kain batik dengan pewarna alami, dan diskusi tentang materi terkait. Sampel pewarna yang sudah didapatkan dari percobaan skala laboratorium juga ditunjukkan kepada petani tembakau. Kegiatan sosialisasi ini dapat dilihat pada Gambar 10. 


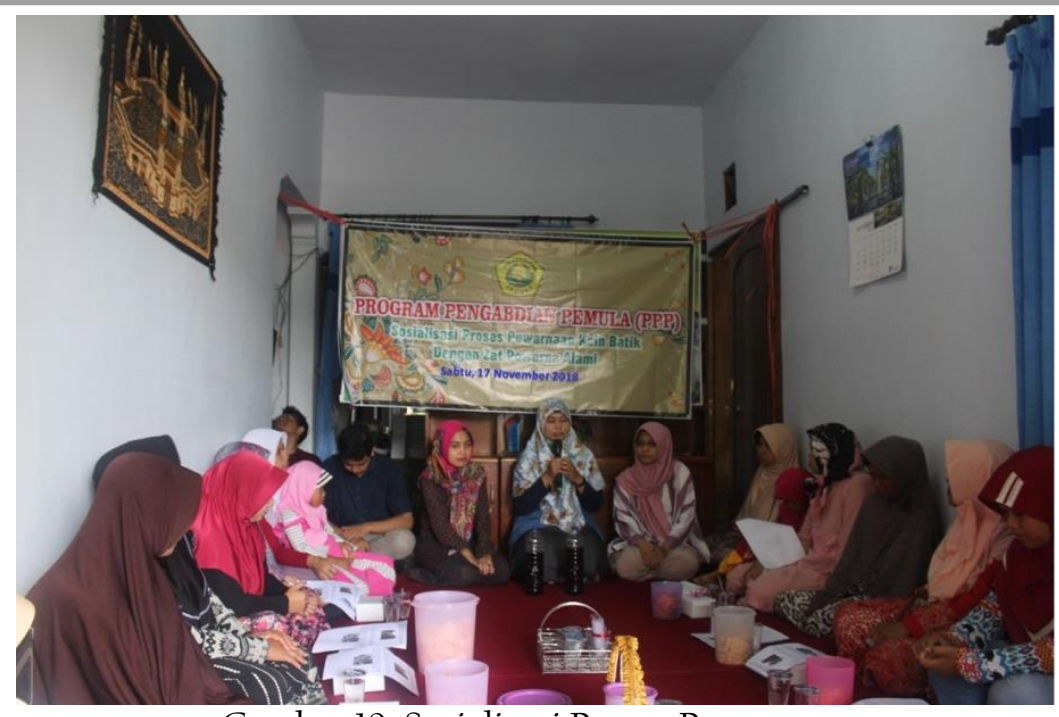

Gambar 10. Sosialisasi Proses Pewarnaan

\section{Praktik Pembuatan Pewarna Alami}

Praktik pembuatan pewarna alami diperagakan oleh pemateri dan diikuti dengan antusias oleh para peserta yang hadir. Bahan dan alat yang digunakan dalam praktik disiapkan oleh pelaksana pengabdian. Kegiatan ini diawali dengan menunjukkan sampel batang tembakau yang sudah dihancurkan dengan mesin pencacah. Tahap awal dilakukan penjelasan terkait langkah awal atau pre-treatment batang tembakau yaitu pengumpulan batang tembakau pasca panen kemudian dilakukan pencucian untuk menghilangkan tanah yang masih menempel kemudian dijemur. Setelah itu, batang tembakau dihancurkan dalam mesin pencacah. Tahap terakhir adalah proses pembuatan pewarna alami dengan proses ekstraksi, dengan merebus batang tembakau dalam air selama l jam. Hasil ekstraksi zat warna berhasil apabila warna berubah menjadi coklat.

Hasil kegiatan praktik pembuatan pewarna alami dari batang tembakau ini, menunjukkan bahwa Kelompok Tani Karunia Tembakau mampu melakukan proses ekstraksi zat pewarna dari batang tembakau. Kendala yang dihadapi adalah kelompok tani membutuhkan waktu dalam proses penghancuran batang tembakau. Produk pewarna batik yang dihasilkan dapat digunakan dalam pencelupan kain batik yang sudah selesai dicanting untuk memberikan warna dasar coklat.

Sesi terakhir sebelum acara ditutup, dilakukan penyerahan sertifikat kepada ketua kelompok tani dan foto bersama antara pelaksana pengabdian, mahasiswa, dan peserta kegiatan pengabdian masyarakat yang dapat dilihat pada Gambar 11.

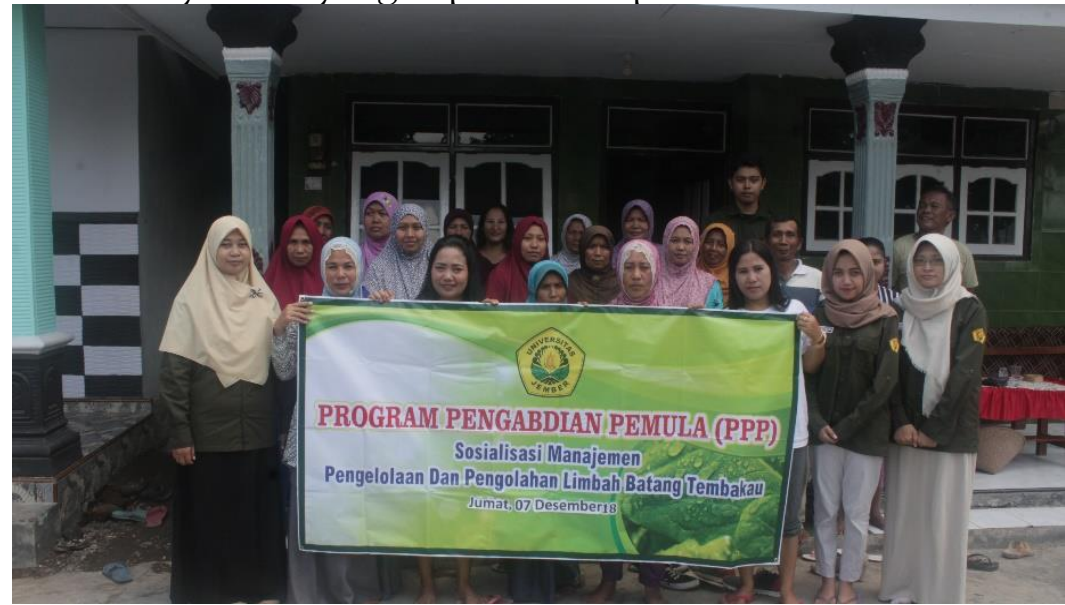

Gambar ll. Foto Bersama dengan Kelompok Tani Karunia Tembakau 


\section{KESIMPULAN}

Program pengabdian masyarakat Fakultas Teknik Universitas Jember dengan mitra Kelompok Tani Karunia Tembakau di Desa Tamansari, Wuluhan yang berupa kegiatan sosialisasi dan pelatihan pembuatan pewarna alami batik dari limbah batang tembakau dalam upaya mengendalikan pencemaran lingkungan dan meningkatkan nilai ekonomis dari limbah batang tembakau dapat diterima dengan baik. Pihak mitra mendapat pengetahuan, keterampilan mengenai pengolahan limbah batang tembakau, proses ekstraksi zat pewarna, cara pembuatan pewarna alami batik dari batang tembakau, dan usaha pembuatan pewarna alami batik dari batang tembakau tersebut dapat dikembangkan secara mandiri dan kontinu, sehingga pada akhirnya dapat meningkatkan pendapatan dan kesejahteraan petani tembakau.

\section{DAFTAR PUSTAKA}

Badan Pusat Statistik Indonesia. "Statistik Indonesia 2017", online: 〈https://www.bps.go.id/publication/2017/07/26/b598fa587f5112432533a656/statistikindonesia-2017.html .

Herawati, W.D. Budidaya Tembakau (Yogyakarta: Trans Idea Publishing, 2016).

Dyaninoor, D. Pewarna Alam pada Batik dari Bahan Daun Tembakau di Perusahaan Pesona Tembakau Temanggung Jawa Tengah (Yogyakarta: UNY, 2012). 